OPEN ACCESS

Approved by:

Frontiers Editorial Office,

Frontiers Media SA, Switzerland

*Correspondence:

Olga A. Zabotina

zabotina@iastate.edu

Specialty section

This article was submitted to Plant Proteomics and Protein

Structural Biology,

a section of the journal

Frontiers in Plant Science

Received: 04 June 2021 Accepted: 07 June 2021

Published: 06 July 2021

Citation:

Zabotina $O A$, Zhang $N$ and Weerts $R$ (2021) Corrigendum: Polysaccharide

Biosynthesis: Glycosyltransferases and Their Complexes.

Front. Plant Sci. 12:720709.

doi: 10.3389/fp/s.2021.720709

\section{Corrigendum: Polysaccharide Biosynthesis: Glycosyltransferases and Their Complexes}

\author{
Olga A. Zabotina*, Ning Zhang and Richard Weerts \\ Roy J. Carver Department of Biochemistry, Biophysics and Molecular Biology, lowa State University, Ames, IA, United States \\ Keywords: polysaccharide biosynthesis, glycosyltransferases, protein complexes, plant Golgi, structural \\ organization
}

\section{A Corrigendum on}

Polysaccharide Biosynthesis: Glycosyltransferases and Their Complexes

by Zabotina, O. A., Zhang, N., and Weerts, R. (2021). Front. Plant Sci. 12:625307. doi: $10.3389 / f p l s .2021 .625307$

The name of the second author "Ning Zhang" was incorrectly spelled as "Ning Zang" in the article when published originally.

The authors apologize for this error and state that this does not change the scientific conclusions of the article in any way. The original article has been updated.

Copyright (c) 2021 Zabotina, Zhang and Weerts. This is an open-access article distributed under the terms of the Creative Commons Attribution License (CC BY). The use, distribution or reproduction in other forums is permitted, provided the original author(s) and the copyright owner(s) are credited and that the original publication in this journal is cited, in accordance with accepted academic practice. No use, distribution or reproduction is permitted which does not comply with these terms. 